\title{
Perjuangan Hidup Tokoh Utama Novel 23 Episentrum Karya Adenita dan Relevansinya terhadap Materi Ajar Sastra di SMA Tinjauan Sosiologi Sastra
}

\author{
Widya Prameswari Pertiwi \\ (corresponding author) \\ Program Studi Pendidikan Bahasa dan Sastra Indonesia \\ Universitas Singaperbangsa Karawang \\ Email: 1710631080166@student.unsika.ac.id \\ Imam Muhtarom \\ Program Studi Pendidikan Bahasa dan Sastra Indonesia \\ Universitas Singaperbangsa Karawang \\ Email: imam.muhtarom@fkip.unsika.ac.id \\ Dewi Herlina Sugiarti \\ Program Studi Pendidikan Bahasa dan Sastra Indonesia \\ Universitas Singaperbangsa Karawang \\ Email: dewi.herlina@fkip.unsika.ac.id
}

APA Citation: Pertiwi, W. P., Muhtarom, I., \& Sugiarti, D. H. (2021). Perjuangan Hidup Tokoh Utama Novel 23 Episentrum Karya Adenita dan Relevansinya terhadap Materi Ajar Sastra di SMA Tinjauan Sosiologi Sastra. Silampari Bisa: Jurnal Penelitian Pendidikan Bahasa Indonesia, Daerah, dan Asing, 4(2), 197-212. https://doi.org/10.31540/silamparibisa.v4i2.1311

\begin{abstract}
Abstrak
Tujuan dilakukannya penelitian ini adalah mendeskripsikan konteks sosial berdasarkan pengaruh pada perjuangan hidup tokoh utama novel 23 Episentrum karya Adenita. Penelitian ini adalah termasuk jenis penelitian kualitatif, jadi metode yang dugunakan adalah deskriptif analisis, yaitu menyajikan data dengan mengandalkan penafsiranpenafsiran untuk memberikan makna perjuangan hidup tokoh utama dalam novel 23 Episentrum. Objek penelitian ini adalah konteks sosial dalam novel. Sumber data penelitian ini adalah novel 23 Episentrum karya Adenita. Teknik pengumpulan data penelitian ini adalah teknik baca, catat, dan dokumentasi. Teknik analisis data dalam penelitian ini adalah pengumpulan data, reduksi data, penyajian data, dan penarikan kesimpulan. Hasil yang diperoleh dari penelitian ini yaitu: (1) analisis perjuangan hidup tokoh utama adalah meliputi perjuangan untuk bertahan hidup, selalu bersyukur, mewujudkan impian, melunasi utang, menjalankan pekerjaan, mendapatkan kebahagiaan, dan untuk meneruskan sebuah kebaikan, serta (2) analisis konteks sosial yang mempengaruhi tokoh utama adalah meliputi pengaruh lingkungan keluarga, pertemanan, dan pekerjaan. Hasil penelitian tersebut direlevansikan untuk digunakan materi ajar sastra di SMA khususnya materi menulis novel.
\end{abstract}

Kata kunci: perjuangan hidup, tokoh utama, novel, konteks sosial, materi ajar sastra 
Widya Prameswari Pertiwi, Imam Muhtarom, Dewi Herlina Sugiarti

Perjuangan Hidup Tokoh Utama Novel 23 Episentrum Karya Adenita dan Relevansinya terhadap Materi Ajar Sastra di SMA Tinjauan Sosiologi Sastra

\title{
The Main Character's Struggle of Life of the Novel 23 Episentrum by Adenita and Her Relevance to Literature Teaching Materials at High School Sociology of Literature Review
}

\begin{abstract}
The purpose of this research was to describe the social context based on the influence on the life struggle of the main character of the novel 23 Episentrum by Adenita. In addition to describing the social context, this study also explores the elements of story building. This research is a type of qualitative research, so the method used is descriptive analysis, namely presenting data by relying on interpretations to become a description. The object of this research is the intrinsic element and social context. The data source of this research is the novel 23 Episentrum by Adenita. The data collection techniques of this research are reading, note-taking, and documentation techniques. Data analysis techniques in this study are data collection, data reduction, data presentation, and drawing conclusions. The results obtained from the research show that (1) the analysis of the main character's life struggle includes the struggle to survive, always be grateful, realize dreams, pay off debts, run jobs, get happiness, and to continue a good. (2) analysis of the social context that affects the main character includes the influence of the family environment, friendships, and work. The results of this study are relevant to literature teaching materials in high school.
\end{abstract}

Keywords: struggle for life, main character, novel, social context, literature teaching materials

\section{A. Pendahuluan}

Menurut Sumaatmadja (dalam Maftuhin dkk., 2016:11), manusia sebagai makhluk hidup yang ada di tengah-tengah manusia lain (lingkungan sosial), dalam konteks budaya (lingkungan budaya), dan alam semesta (lingkungan alam). Di samping memiliki sifat-sifat yang berbeda, manusia juga memiliki pelbagai persamaan antarmanusia. Maka dari itu, manusia sangat menarik untuk diteliti dan diamati setiap proses kehidupannya.

Cerminan kehidupan dapat ditemukan pada karya sastra, karena di dalamnya terdapat kisah perjalaan hidup tokoh yang berhasil dibangun oleh seorang penulis untuk dapat dinikmati pembacanya. Salah satu karya sastra yang bisa dengan rinci menyajikan suatu cerita atau kisah kehidupan adalah sebuah novel. Menurut Nurgiyantoro (2013:17), yang dihadirkan oleh novel merupakan dunia dalam skala yang lebih besar dan kompleks yang mencakup pelbagai pengalaman kehidupan yang dipandang aktual, namun semuanya tetap saling berjalin.

Menurut Nurgiyantoro (dalam Nilawijaya dan Awalludin, 2021:15), mendefinisikan novel sebagai salah satu dari karya fiksi yang menawarkan sebuah dunia, dunia tersebut berisi model kehidupan yang diidealkan, imajinatif, dan yang membangun melalui unsur intrinsiknya. Menurut Nurgiyantoro (2013:30), sebuah novel memiliki unsur-unsur pembangun di dalamnya, sehingga harus adanya pengkajian terlebih dahulu sebelum memasuki pada masalah penelitian, terutama yang berkaitan dengan unsur intrinsik sebuah novel. Karena unsur intrinsik sebuah novel adalah unsur-unsur yang (secara langsung) turut serta dalam membangun cerita. 
Widya Prameswari Pertiwi, Imam Muhtarom, Dewi Herlina Sugiarti

Perjuangan Hidup Tokoh Utama Novel 23 Episentrum Karya Adenita dan Relevansinya terhadap Materi Ajar Sastra di SMA Tinjauan Sosiologi Sastra

Penelitian ini mengenai sebuah novel yang berjudul 23 Episentrum. Perjalanan berharga dari kehidupan tokoh dalam novel 23 Episentrum dapat dipelajari untuk menjadi renungan bagi kehidupan sosial masyarakat. Novel 23 Episentrum merupakan novel yang ditulis oleh Yuli Anita atau lebih dikenal sebagai Adenita. Perjalanan hidup yang paling dominan dalam novel 23 Episentrum (2012) adalah perjalanan dari tokoh Matari Anas yang merupakan tokoh utama. Menurut Nurgiyantoro (2013 : 259), tokoh utama adalah tokoh yang diutamakan penceritaannya dalam sebuah novel. la merupakan tokoh yang paling banyak diceritakan. Baik sebagai pelaku kejadian maupun yang dikenai kejadian.

Masalah penelitian ini berkaitan dengan tema yang ditemukan, yaitu sebuah perjuangan hidup yang dialami oleh tokoh utama. Perjuangan hidup tokoh utama dalam penelitian ini adalah meliputi; 1) perjuangan dalam bertahan hidup, 2) perjuangan untuk tetap bersyukur, 3) perjuangan dalam mewujudkan impian, 4) perjuangan untuk melunasi utang, 5) perjuangan dalam menjalankan pekerjaan, 6) perjuangan dalam mendapat kebahagiaan, dan 7) perjuangan dalam meneruskan kebaikan.

Banyak hal yang diperjuangkan oleh Matari. Seperti yang dikatakan oleh orang Inggris (dalam Manesah, 2016 : 181), life is a strunggle, hidup adalah sebuah perjuangan. Artinya, dalam hidup ini harus ada sebuah usaha dari diri sendiri untuk bisa maju. Ketika sudah tidak ada semangat dalam diri untuk maju, maka bisa dipastikan akan menjadi seorang pecundang dalam kehidupannya sendiri. Bahkan, bisa saja hanya menyalahkan keadaan, diri sendiri, atau orang lain ketika kehidupannya menjadi tidak sesuai dengan yang diharapkan.

Realitas sosial dalam novel 23 Episentrum memberikan cerminan tentang fenomena yang terjadi di kehidupan nyata, seperti keadaan perekonomian yang sulit, situasi dan kondisi yang tidak mendukung untuk mengejar cita-cita, sulit mendapatkan kesempatan untuk mewujudkan keinginan, atau keadaan yang mendesak untuk menjalani hidup secara terpaksa. Semua itu dapat dipengaruhi oleh lingkungan sosial yang memberi pengaruh yang baik atau buruk bagi seseorang. Lingkungan yang dimaksud adalah seperti lingkungan keluarga, pertemanan, dan lingkungan pekerjaan.

Karena adanya hubungan sosial yang terjalin dalam kehidupan tokoh utama novel 23 Episentrum karya Adenita, maka penelitian ini dianalisis berdasarkan tinjauan sosiologi karya sastra. Hal itu dilakukan karena sasaran penelitian ini adalah memfokuskan pada konteks sosial yang mempengaruhi tokoh utama. Menurut Kurniawan (2012 : 11), sosiologi karya sastra adalah analisis sosiologi yang kedua dan berangkat dari karya sastra. Artinya, analisis terhadap aspek sosial dalam karya sastra dilakukan dalam rangka untuk memahami dan memaknai hubungannya dengan keadaan sosial masyarakat di luarnya .

Menganalisis konteks sosial dalam sebuah novel berkaitan dengan nilai sosial yang terkandung di dalamnya (Sulaeman dkk., 2020: 611-612). Menurut Young (dalam Nugroho dan Yasafiq, 2019:32), nilai sosial adalah asumsi abstrak dan sering tidak disadari mengenai apa yang dianggap benar dan yang penting. Nilai sosial lebih ditekankan sebagai petunjuk arah demi tercapainya tujuan sosial masyarakat. Nilai sosial juga dapat mendorong pembaca untuk dapat bersikap atau bertingkah laku ke arah yang lebih baik. Sehingga nilai sosial merupakan nilai yang mencerminkan suatu usaha dari setiap manusia untuk dapat menyesuaikan diri terhadap lingkungan sosialnya.

Silampari Bisa: Jurnal Penelitian Pendidikan Bahasa Indonesia, Daerah, dan Asing Vol. 4, No. 2, 2021 
Widya Prameswari Pertiwi, Imam Muhtarom, Dewi Herlina Sugiarti

Perjuangan Hidup Tokoh Utama Novel 23 Episentrum Karya Adenita dan Relevansinya terhadap Materi Ajar Sastra di SMA Tinjauan Sosiologi Sastra

Mempelajari karya sastra sangatlah penting dalam perkembangan pembelajaran sastra di sekolah. Adanya karya sastra akan memberikan pengaruh dalam pertumbuhan karakter peserta didik. Menurut Dewi dkk., (2014:4), sastra menyajikan sebuah gambaran kehidupan yang sebagian besar terdiri dari kenyataan sosial. Dalam pengertian ini, kehidupan mencakup hubungan antar masyarakat, antar manusia, dan antar peristiwa yang terjadi dalam batin seseorang. Kriteria utama yang dikenakan karya sastra adalah sebuah kebenaran penggambaran atau yang hendak digambarkan. Hubungan pertumbuhan karakter dengan pernyataan tersebut adalah, sebuah karya sastra dapat menjadi salah satu sarana untuk dapat dipelajari nilai-nilai yang terkandung di dalamnya. Karena kisah di dalam karya sastra mungkin saja sebuah peristiwa yang dapat menjadi cerminan kehidupan.

Menurut Herfanda (dalam Suryaman, Maman. 2010:114), sastra memiliki potensi yang besar untuk membawa masyarakat ke arah perubahan, termasuk perubahan pada karakter. Sebagai ekspresi seni bahasa yang bersifat reflektif segaligus interaktif. Sastra dapat menjadi spirit bagi munculnya sebuah gerakan perubahan masyarakat, bahkan kebangkitan suatu bangsa ke arah yang lebih baik. Adanya penguatan rasa cinta tanah air, serta sumber inspirasi dan motivasi kekuatan moral bagi perubahan sosial budaya masyarakat.

Maka dari itu, peneliti tertarik untuk memanfaatkan novel 23 Episentrum karya Adenita untuk dilihat bagaimana relevansinya melalui wujud perjuangan hidup tokoh utama berdasarkan konteks sosialnya. Jadi, tujuan penelitian ini adalah menganalisis wujud perjuangan hidup tokoh utama dengan konteks sosial yang mempengaruhinya. Peserta didik dapat mempelajari kisah perjalanan hidup tentang kerja keras, pengorbanan, keyakinan, dukungan dari lingkungan sekitar, memilih pergaulan yang tepat, dan yang pasti harus selalu bersyukur atas apapun yang terjadi. Memanfaatkan novel 23 Episentrum karya Adenita dalam pembelajaran sastra tingkat Sekolah Menengah Atas (SMA), dapat menjadi salah satu pilihan yang tepat dan diharapkan memberi pengaruh yang positif bagi peserta didik.

\section{B. Metode Penelitian}

Penelitian ini termasuk dalam jenis kualitatif, yaitu menggunakan metode deskriptif analisis. Penelitian dilakukan untuk menganalisis secara keseluruhan dengan memanfaatkan cara-cara penafsiran sehingga dapat menyajikan hasil penelitian dalam bentuk deskripsi. Data dalam penelitian ini adalah berupa sebuah narasi dan percakapan yang dikutip dari sumber data yaitu novel 23 Episentrum karya Adenita. Sebuah novel yang mencerminkan konteks sosial dengan digambarkan melalui perjuangan hidup tokoh utamanya. Jadi, sumber data utama dalam penelitian ini adalah novel 23 Episentrum karya Adenita, diterbitkan oleh PT. Grasindo, diterbitkan tahun 2012, dan jumlah halamannya 278 halaman.

Adapun teknik dalam pengumpulan data penelitian kualitatif ini adalah teknik baca, teknik catat, dan teknik dokumentasi. Instrumen utama penelitian ini adalah peneliti itu sendiri, dengan menggunkan sebuah pedoman dalam menganalisis masalah penelitian. Pedoman analisis yang digunakan adalah: pedoman analisis unsur intrinsik, pedoman analisis perjuangan hidup tokoh utama, dan pedoman 
Widya Prameswari Pertiwi, Imam Muhtarom, Dewi Herlina Sugiarti

Perjuangan Hidup Tokoh Utama Novel 23 Episentrum Karya Adenita dan Relevansinya terhadap Materi Ajar Sastra di SMA Tinjauan Sosiologi Sastra

analisis konteks sosial yang mempengaruhi tokoh utama novel 23 Episentrum karya Adenita. Pedoman analisis tersebut dibuat dalam bentuk tabel yang terdiri atas aspek yang diteliti dan indikator analisis penelitian berupa pertanyaan yang berkaitan dengan rumusan masalah. Analisis dalam penelitian ini dilakukan berdasarkan teknik yang digunakan, yaitu setelah sumber data dibaca secara menyeluruh dan mendalam akan dibuat sebuah catatan-catatan berupa data mentah.

Selanjutnya, teknik analisis data yang digunakan dalam penelitian ini adalah pengumpulan data, reduksi data, penyajian data, dan penarikan kesimpulan. Adanya pengujian terhadap data yang telah dikumpulkan melalui pengklasifikasian data dan menginterpretasi data sehingga menjadi sebuah deskripsi yang utuh dan mendalam. Data yang masih bersifat mentahan akan melewati tahap reduksi data sesuai dengan urutan konteks permasalahan penelitian. Selanjutnya, peneliti dapat membuat suatu kesimpulan atau menyimpulkan hasil akhir dari analisis penelitiannya. Hasil analisis dari penelitian ini adalah berupa konteks sosial dalam novel 23 Episentrum karya Adenita untuk selanjutnya direlevansikan terhadap materi ajar sastra di SMA.

\section{Hasil Penelitian dan Pembahasan}

\section{Hasil Penelitian}

a. Analisis Konteks Sosial yang Mempengaruhi Tokoh Utama Novel 23 Episentrum Karya Adenita

1) Pengaruh Lingkungan Keluarga

Keadaan perekonomian keluarga Matari yang sulit, membuatnya terhambat untuk kuliah dan menyelesaikan kuliahnya. Banyak faktor yang membuatnya kesulitan untuk menyelesaikan kuliah, terutama dalam hal yang berkaitan dengan pembayaran kuliah. Karena untuk bisa melanjutkan ke semester berikutnya, biasanya harus menyelesaikan biaya kuliah pada semester yang sedang dijalani.

...Tari baru saja hendak memulai. Telat masuk, telat keluar, tapi paling tidak ia tidak terlalu terlambat untuk meraih impiannya menjadi sarjana di tengah kondisi karut-marut ekonomi keluarganya... (Adenita, 2012:5).

Kutipan lain yang mendukung untuk menggambarkan keadaan perekonomian Matari adalah karena hal yang melatarbelakanginya, yaitu kondisi Ayahnya yang menjadi korban PHK. Hal tersebut yang mengakibatkan Matari harus memperjuangkan kuliahnya dengan tanpa bantuan dari keluarganya.

\footnotetext{
...Bodoh. Tidak berstrategi. Apa pun sebutannya tapi itulah yang terjadi saat itu. Saat bapaknya yang korban PHK tidak percaya lagi pada pendidikan yang bisa mengubah nasib, saat pilihan beasiswa tidak meliriknya karena tidak ada yang istimewa darinya... (Adenita, 2012:71).
}

Kondisi keluarga yang tidak mendukung, membuat Matari harus terpaksa mencari cara agar tetap bisa kuliah dan mewujudkan impiannya. Tidak ada cara lain yang bisa dilakukan bagi Matari yang berada dalam keluarga menengah ke bawah, selain dengan cara berutang. 
Widya Prameswari Pertiwi, Imam Muhtarom, Dewi Herlina Sugiarti

Perjuangan Hidup Tokoh Utama Novel 23 Episentrum Karya Adenita dan Relevansinya terhadap Materi Ajar Sastra di SMA Tinjauan Sosiologi Sastra

...Tapi, bagi keluarga kecil yang berpenghasilan pas-pasan seperti keluarganya, kuliah menjadi sebuah permintaan yang membuat hati orang tuanya gentar. Tak heran jika banyak orang tua yang kemudian mesti berutang demi meluluskan permintaan anaknya untuk tetap sekolah... (Adenita, 2012:82).

Kutipan di atas menggambarkan bahwa dengan cara berutang adalah sebuah cara bagi keluarga yang memiliki penghasilan pas-pasan untuk dapat mewujudkan sebuah impian melalui sekolah. Tetapi, yang dialami oleh Matari bukanlah mengandalkan orang tuanya yang berutang, melainkan dirinya sendiri yang berutang pada teman-temannya. Matari yang memutuskan sendiri untuk melanjutkan kuliah, maka ia pun harus memutuskan sendiri sebuah cara dan risiko yang akan dihadapinya.

\section{2) Pengaruh Lingkungan Pertemanan}

Lingkungan pertemanan Matari sangat memberikan pengaruh bagi kehidupannya, karena melalui teman-temannya lah ia bisa meminjam uang untuk menyelesaikan kuliah. Matari memiliki lingkungan pertemanan yang baik dan dapat memberi pengaruh yang baik pula bagi kehidupannya.

...Sejak masih di bangku kuliah dulu, Awan sudah sering membantunya merumuskan strategi. Awan memang bukan konsultan keuangan yang profesional, tapi Tari tahu bahwa Awan selalu piawai untuk menghitung peluang... (Adenita, 2012:41).

Awan adalah sahabat baik Matari sejak kuliah, ia selalu mendukung dan membantu Matari, terutama dalam hal masalah utangnya. Matari menjadikan Awan sebagai seorang konsultan keuangannya, dengan membantu menyusun strategi dan mencari solusi bagi masalah keuangannya. Awan adalah seorang bankir, dan tentu itu menjadi hal yang biasa baginya untuk sebuah hal yang berkaitan dengan uang. Keberadaan Awan juga sangat memberikan pengaruh baik bagi Matari, selain dapat memberi solusi, Awan juga sering membangkitkan kembali semangat Matari ketika mulai merasa putus asa.

"Keyakinan kecil yang baru aja lo sebut itu seperti nyala sebuah lilin dalam gelap, Tar. Mungkin memang nggak bisa melihat semua, tapi setidaknya lilin itu yang akan menuntun lo mencari jalan keluar. Pegang aja keyakinan yang ada itu dalam hati dan pikiran lo. Semoga itu yang akan membuat bayak hal leleh dengan api keyakinan yang lo punya."

"Thanks, Wan.. sangat menyejukkan (Adenita, 2012:49)."

Kutipan di atas menggambarkan bahwa Matari yang sebelumnya sudah goyah keyakinannya dan hampir putus asa, dapat dibantu dengan dukungan dari sahabatnya yang berusaha meyakinkannya lagi. Selain itu, pengaruh dari lingkungan perteman Matari adalah berkaitan dengan teman-temannya yang telah membantu mengulurkan tangan untuk membantu meminjamkan uang. Uang yang dapat membuatnya bisa menyelesaikan kuliah dan menjemput peluang untuk mewujdukan impiannya. Hal tersebut dapat dibuktikan dengan kutipan berikut. 
Widya Prameswari Pertiwi, Imam Muhtarom, Dewi Herlina Sugiarti

Perjuangan Hidup Tokoh Utama Novel 23 Episentrum Karya Adenita dan Relevansinya terhadap Materi Ajar Sastra di SMA Tinjauan Sosiologi Sastra

Tari merinding menyaksikan bagaimana ion-ion kebaikan melingkari hidupnya. la seperti dikelilingi oleh ratusan malaikat yang menyambungkan tangannya lewat orangorang pilihannya... (Adenita, 2012:242).

\title{
3) Pengaruh Lingkungan Pekerjaan
}

Untuk mewujdukan sebuah impian, Matari harus berada di lingkungan pekerjaan yang akan mengantarkannya pada sebuah cita-cita. Lingkungan pekerjaan tentu memberikan pengaruh bagi kehidupan dan perilaku Matari.

\begin{abstract}
Satu hal yang selalu membuat Tari untuk datang lebih awal ke kantor adalah karena ia bisa ber-Internet dengan bebas dan karena selalu ada sisa jatah makanan katering pagi hari. Biasanya produser yang kerja shift malam sudah terlanjur lelah dan jarang mengambil jatah makan pagi mereka. Sebuah cara penghematan yang tidak diketahui, kecuali oleh Opiq yang rajin memprioritaskan jatah katering sisa untuk Matari. Plus teh manis hangat di pagi hari, atau teh manis dingin saat ia sore hari pulang liputan. Opiq memang juara menghafal kebiasaan seisi kantor (Adenita, 2012:76).
\end{abstract}

Kutipan tersebut menggambarkan bahwa Matari berada di lingkungan yang cukup baik, karena ada kebaikan dan perhatian yang didapatkannya dari orang lain. Seorang OB yang bernama Opiq memang sangat mengerti dengan keadaan Matari, itu memang sebuah tugas dan tanggung jawab Opiq untuk membantu karyawan yang bekerja. Tetapi, Opiq memanglah memiliki sikap yang baik, ramah, dan gesit dalam bekerja. Selain sikap baik yang didapatkan oleh Matari di lingkungan pekerjaan, tentu ada pula sikap yang sudah lumrah antara ketegasan seorang atasan kepada bawahannya.

"Kejar dong! Harus gesit kalau jadi reporter, jangan klemar-klemer." Suara bossy Mbak Bella mulai keluar. Matari menarik napas panjang. Ingin rasanya ia memaki orang di ujung telepon sana. Rasa lapar yang mendera membuat sumbu emosinya mudah tersulut. Sejujurnya, ini bukan waktu yang tepat untuk berdebat dengan Mbak Bella (Adenita, 2012:181)."

Kutipan di atas menggambarkan keadaan Matari yang merasa emosi karena respons Mbak Bella yang tidak lain adalah salah satu produsernya. Mbak Bella memarahi Matari melalui sebuah telepon dengan cara mengata-ngatainya. Keadaan seperti itu sudah tidak asing terjadi di dunia pekerjaan, ketegasan dan kemarahan seorang atasan pada bawahannya. Hal tersebut tentu membuat Matari merasa kesal, karena usahanya di lapangan seolah tidak dianggap. Namun, tidak semua atasan akan bersikap demikian, pasti ada kalanya Matari mendapatkan sikap baik dan seolah ada yang membelanya.

"Ya Tuhan! Bella! Tolong panggil Mbak Dudu sekarang penting!" Mas Zaki setengah berteriak. Mbak Bella meninggalkan tatapan tajam pada Matari.

"Gila... ini gila!" Mas Zaki terus memandangi layar monitor yag memutar liputan hasil Matari dan Gusti... (Adenita, 2012:192)."

Kutipan tersebut adalah sebuah bantahan dari produser lain, Mas Zaki terhadap Mbak bella yang selalu memarahi Matari dan mudah menganggapnya melakukan kesalahan. Pada saat itu, ternyata Matari membuat sebuah prestasi baru dengan memiliki hasil liputan yang aktual dan beritanya belum dimiliki oleh 
Widya Prameswari Pertiwi, Imam Muhtarom, Dewi Herlina Sugiarti

Perjuangan Hidup Tokoh Utama Novel 23 Episentrum Karya Adenita dan Relevansinya terhadap Materi Ajar Sastra di SMA Tinjauan Sosiologi Sastra

stasiun televisi lain. Maka pengaruh yang didapatkan oleh Matari adalah adanya sebuah penghargaan yang didapatkannya, meski sebelumnya mendapatkan amarah dari Mbak Bella.

\title{
b. Analisis Perjuangan Hidup Tokoh Utama Novel 23 Episentrum Karya Adenita
}

1) Perjuangan untuk Bertahan Hidup

Bertahan hidup di sini adalah berarti sebuah usaha yang dilakukan oleh Matari Anas, yang ingin tetap memperjuangan hidupnya dan melewati setiap rintangan atau ujian yang datang.

\begin{abstract}
Matari Anas, seorang Sarjana Komunikasi Universitas Panaitan, Bandung, yang merasa terlambat memulai kariernya. Di saat teman-teman seangkatannya sudah lulus dan menjadi kutu loncat dalam bekerja. Tari baru saja hendak memulai. Telat masuk, telat keluar, tapi paling tidak belum terlalu terlambat untuk meraih impiannya menjadi sarjana di tengah kondisi karut-marut ekonomi keluarganya. Karenanya, ia tak mau lagi merasa menjadi orang yang telat dalam mendulang kesempatan (Adenita, 2012:5).
\end{abstract}

Kutipan tersebut membuktikan bahwa Matari tetap ingin melanjutkan kehidupannya dan berhasil menjadi seorang sarjana, meskipun keadaan perekonomian yang sulit dan tidak bisa membantunya untuk kuliah. Kutipan lain yang membuktikan bahwa Matari tidak menyerah dengan keadaannya adalah sebagai berikut.

Kini, babak menjadi sarjana sudah usai. Tari telah mengunyah pelajaran berharga dalam hidupnya. Entah pelajaran nomor berapa, yang jelas saat ini ia tengah belajar dengan keras akan arti tanggung jawab. Tanggung jawab atas segala langkah yang telah dipilihnya. Langkahnya untuk bersekolah tinggi atas nama cita-cita dan sebuah kemajuan serta masa depan yang lebih baik... (Adenita, 2012:83).

Berdasarkan beberapa data kutipan di atas, menunjukkan bahwa perjuangan Matari dalam bertahan hidup melewati proses yang panjang. Dimulai dari faktor perekonomian keluarga yang sulit karena ayahnya terkena PHK dan membuatnya harus mandiri untuk meneruskan keinginannya berkuliah. Matari tidak menginginkan jika kehidupannya berhenti dengan menerima keadaan keluarganya yang masih mengalami kesulitan dalam hal perekonomian.

\section{2) Perjuangan untuk Selalu Bersyukur}

Perjuangan hidup Matari yang harus selalu menerima setiap keadaan dan harus selalu bersyukur dengan tetap berusaha menjalani kehidupannya. Matari menyadari betul, bahwa dengan masalah-masalah yang dihadapinya mungkin saja tidak sebanding dengan yang dialami oleh orang lain. Karena masih banyak orang yang pengalaman hidupnya mungkin lebih sulit daripadanya.

\footnotetext{
"Tari melambaikan tangan pada Opiq yang selalu tersenyum dan menyapa orang lain itu. Sepanjang jalan keluar kompleks kantornya. Tari tiba-tiba merasa semakin bersyukur, gelar sarjananya sudah memberikan pilihan lebih banyak untuk bekerja. Entah apa jadinya jika ia bernasib seperti Opiq... (Adenita, 2012:10)."
} 
Widya Prameswari Pertiwi, Imam Muhtarom, Dewi Herlina Sugiarti

Perjuangan Hidup Tokoh Utama Novel 23 Episentrum Karya Adenita dan Relevansinya terhadap Materi Ajar Sastra di SMA Tinjauan Sosiologi Sastra

Berdasarkan kutipan di atas, Matari merasa bersyukur karena tidak memiliki nasib yang sama dengan Opiq, seorang office boy $(O B)$ yang bekerja di kantor Tari. Pekerjaan yang harus dimiliki karena terpaksa menyerah pada keadaan yang mengharuskannya untuk berhenti sekolah. Mungkin saja, jika dulu Matari tidak nekat akan hidup dan ambisinya, nasibnya tidak akan seperti sekarang ini. Bagaimanapun juga, saat ini ia sudah lulus kuliah dan dapat memiliki pekerjaan yang sesuai dengan bidang dan keinginannya. Itulah yang harus selalu Matari ingat untuk dapat disyukuri. Kutipan lain yang mendukung adalah sebagai berikut.

\begin{abstract}
...Dalam sesaknya Metro Mini yang lantainya bolong dan kaca yang retak, tari mensyukuri nasibnya saat ini. la tersenyum mengingat sebuah cita-cita yang pernah terlintas dalam benaknya dulu, menjadi news anchor. Meski ia belum benar-benar tampil di layar kaca, rasanya ada sesuatu yang menyelinap di dadanya, kebanggaan (Adenita, 2012:11).
\end{abstract}

Data di atas menunjukkan rasa syukur yang selalu Matari pertahankan menyimpan sebuah cobaan dalam hidupnya. Bukan sebuah cara yang mudah untuk mempertahankan rasa syukur dalam hidup, akan ada ujian dan rintangan yang harus dihadapi. Matari bersyukur atas apa yang telah dimilikinya saat ini, sebuah pekerjaan yang akan mengantarkannya pada impiannya sejak kecil. Namun, semua itu ternyata sempat tergoyahkan karena waktu libur yang dimilikinya saat ini menjadi sangat sedikit dan tidak menentu.

\title{
3) Perjuangan dalam Mewujudkan Impian
}

Keinginan Matari untuk melanjutkan kuliah adalah karena sebuah impian yang ingin diwujudkan. Seorang news anchor, itulah cita-cita dan impian yang dimiliki oleh Matari sejak dahulu. Tetapi semua perjuangannya belum selesai sampai lulus kuliah, untuk memasuki dunia yang menjadi impiannya, begitu banyak proses yang harus dilewatinya. Pekerjaan yang didapatkannya pun bukanlah langsung menjadi seorang news anchor, tetapi menjadi seorang reporter. Itulah proses dan perjuangan Matari selanjutnya untuk sampai pada impiannya.

"Wah panjang juga ya Mbak, jalannya."

"Begitulah, makanya banyak yang berguguran, dikiranya gampang jadi news anchor, tinggal baca telepromter, enak aja... Isi kepala dan mentalnya harus diuji dulu. Kamu sanggup, nggak?" (Adenita, 2012:7)

Kutipan di atas membuktikan bahwa perjalanan menjadi seorang news anchor tidaklah mudah. Jika Matari memang menginginkan impiannya terwujud, maka ia harus mampu bertahan dan terus melewati setiap prosesnya. Di balik itu semua, saat ini Matari sudah merasa bangga karena berada di posisinya sekarang. Seorang reporter di salah satu stasiun televisi. Semua itu didapatkan karena ia berhasil menyelesaikan kuliahnya. Kutipan pendukung lainnya adalah sebagai berikut.

\footnotetext{
"Apa tujuan kamu jadi reporter?"

"Karena saya mau jadi news anchor dan jalannya lewat sini dulu, Mbak."

"Kenapa news anchor?"

"Karena, karena dari dulu saya suka itu, dan saya ingin sekali menjadi orang yang memberi informasi pada dunia."
} 
Widya Prameswari Pertiwi, Imam Muhtarom, Dewi Herlina Sugiarti

Perjuangan Hidup Tokoh Utama Novel 23 Episentrum Karya Adenita dan Relevansinya terhadap Materi Ajar Sastra di SMA Tinjauan Sosiologi Sastra

"Kalau kamu tidak bermasalah dengan keuangan, apakah kamu akan meneruskan pekerjaan ini?"

"Ya, Mbak (Adenita, 2012:203)."

Kutipan tersebut menggambarkan keadaan Matari yang sedang dalam kegelisahan, di sisi lain ia menginginkan pekerjaan itu untuk dapat mencapai citacitanya, di sisi lain ada sebuah masalah keuangan yang dialaminya. Persoalan memiliki sebuah utang puluhan juta menjadi kegundahannya, karena gaji menjadi seorang reporter masih belum membuatnya menyelesaikan semua utang itu dengan cepat. Karena hal itu, Matari mulai merasa untuk mencari pekerjaan dengan gaji yang lebih tinggi dari seorang reporter.

\title{
4) Perjuangan untuk Melunasi Utang
}

Persoalan utang akan menjadi tujuan hidup Matari setelah lulus kuliah, karena utang itu memang dimilikinya sebagai sebuah cara untuk bisa melanjutkan kuliah dan mencapai impiannya.

...Yang belum berhasil saat ini adalah membebaskan diri dari lilitan utang yang digunakan untuk membayar impiannya dulu: bersekolah tinggi. Ketidakmampuan orang tua dan ketidakberuntungan mendapatkan beasiswa melahirkan sebuah tekad yang dicibir orang sebagai langkah nekat untuk tetap bersekolah, yakni berutang (Adenita, 2012:11-12).

Itulah cara yang bisa dilakukan oleh Matari untuk melanjutkan kuliah dan menyelesaikannya sampai lulus, dengan berutang. Perjuangan yang harus melewati perjalanan panjang dengan kerja keras yang mungkin tidak boleh padam. Karena utang puluhan juta, bukanlah utang yang kecil bagi seorang Matari yang masih berusia 26 tahun.

\begin{abstract}
Utang yang kini harus dihadapinya. Babak baru dalam hidupnya adalah menyelesaikan utang biaya sekolahnya. Total biaya kuliah dan hidupnya hingga berhasil mengenakan toga sekitar 70 juta rupiah. Angka yang fantastis itu sebagian masih menjadi beban hidupnya saat itu, meski sudah menyusut karena telah ia cicil selama bekerja di bangku kuliah dulu. Maka, setelah ditotal ulang, utang yang tersisa adalah 55 juta rupiah. Jumlah yang sangat besar untuk dihadapinya di usia yang baru 26 tahun, tapi itulah realitas (Adenita, 2012:12)
\end{abstract}

Sebuah angka yang sangat besar bagi seorang Matari, utang yang harus dibayarnya sebagai cara untuk mewujudkan impiannya. Sebuah utang yang mejadi beban dalam hidupnya, harus terus diperjuangkan agar kehidupannya dapat menjadi lebih leluasa. Utang yang dimilikinya saat ini, memang sebuah risiko yang harus dihadapinya. Apa yang telah ia mulai sebelumnya, tentu harus ia selesaikan dengan segala risikonya.

\section{5) Perjuangan dalam Menjalankan Pekerjaan}

Untuk memperjuangkan tujuan hidupnya, Matari harus memperjuangkan pekerjaannya. Tujuan hidupnya adalah untuk bisa mencapai impiannya, sehingga dapat membantu merubah perekonomian keluarga. Tetapi, ada tujuan lain di balik itu semua, yaitu sebuah utang yang harus segera ia selesaikan. Menjalankan

Silampari Bisa: Jurnal Penelitian Pendidikan Bahasa Indonesia, Daerah, dan Asing Vol. 4, No. 2, 2021 
Widya Prameswari Pertiwi, Imam Muhtarom, Dewi Herlina Sugiarti

Perjuangan Hidup Tokoh Utama Novel 23 Episentrum Karya Adenita dan Relevansinya terhadap Materi Ajar Sastra di SMA Tinjauan Sosiologi Sastra

pekerjaan yang bisa menjadi kesempatan untuk mencapai tujuan hidupnya, tidak akan semudah yang dibayangkan. Akan ada banyak tantangan dari setiap prosesnya, apalagi ketika Matari sudah terjun ke lapangan untuk menyampaikan sebuah berita, tentu banyak hal yang harus dihadapinya.

\begin{abstract}
...Musim hujan adalah petaka. Dan petaka juga bagi Matari karena hampir 3 minggu ia harus liputan ke wilayah banjir di penjuru Jakarta. Mulai dari memantau debit air di pintu-pintu air, perkembangan rumah-rumah yang terendam banjir, anak-anak yang tidak bisa sekolah, tanggul jebol, warga kesulitan air bersih, solusi pemerintah. Semua itu menjadi variasi berita tiga minggu yang membuat Matari jenuh. Pergi pagi pulang sore dengan baju yang sudah bau apek. Belum lagi kaki yang gatal-gatal karena harus turun ke daerah banjir yang airnya sudah menyatu dengan air selokan... (Adenita, 2012:149)
\end{abstract}

Berdasarkan kutipan di atas, begitu terlihat bagaimana perjuangan seorang Matari sebagai reporter. Harus siap terjun ke lapangan dengan setiap kondisi, apapun harus dilakukan demi mendapatkan berita yang sesuai dengan topik terkini. Bukan hanya karena setiap kondisi lapangan yang berbeda, tetapi juga karena setiap respons dari atasannya yang tidak selalu baik. Dengan kondisi Matari yang lelah baru selesai terjun ke lapangan untuk membuat liputan, harus juga menerima setiap kritik, kemarahan, atau ketegasan dari atasannya. Seperti pada kutipan berikut, salah seorang produser yang menganggap Matari membuat suatu kesalahan.

\footnotetext{
...Baru saja ia berniat merebahkan diri sebentar di sofa lobi, Mbak Bella melintas dan langsung memanggilnya ke ruang produser.

Kamu kenapa sih? Selalu bikin masalah.. liputan ini nggak dapet, cari soundbite narasumber aja susah banget, lelet kalo disuruh apa-apa.. sekarang apa maksud kamu ngasih izin Gusti buat ngambil gambar? Mbak Bella memuntahkan kekesalannya pada Matari (Adenita, 2012:191).
}

Kutipan di atas menggambarkan kondisi Matari yang sudah kelelahan karena baru sampai ke kantor dari tempat liputannya, tetapi harus menerima kekesalan dari atasannya juga. Padahal, kondisi di lapangan yang membuatnya terdesak dan terpaksa memberikan kamera kepada Gusti untuk merekamnya. Seorang kameramen yang saat itu bertugas dengannya sedang pergi dan tidak bisa dihubungi, padahal ada sebuah momen penting yang harus segera direkam.

\title{
6) Perjuangan dalam Mendapatkan Kebahagiaan
}

Sebuah kebahagiaan yang ingin didapatkan oleh Matari adalah dengan sebuah impian menjadi news anchor dapat terwujud. Matari merasa pekerjaannya menjadi seorang reporter adalah suatu hal yang menyenangkan.

Hari bertemu minggu dan menggenap menjadi bulan. Enam bulan sudah Tari bekerja sebagai reporter. Pekerjaan yang menyenangkan baginya, tapi tidak menyenangkan bagi segala target yang telah direncanakan dulu. Tari merasa kewalahan dalam memenuhi targetnya untuk melunasi utang...(Adenita, 2012:40).

Berdasarkan kutipan tersebut, kebahagiaan yang ingin didapatkannya melalui sebuah pekerjaan, dapat terwujud ketika salah satu tujuan hidupnya untuk 
Widya Prameswari Pertiwi, Imam Muhtarom, Dewi Herlina Sugiarti

Perjuangan Hidup Tokoh Utama Novel 23 Episentrum Karya Adenita dan Relevansinya terhadap Materi Ajar Sastra di SMA Tinjauan Sosiologi Sastra

melunasi utang sudah selesai. Karena bagi Matari, dengan utang yang belum terselesaikan membuatnya terbatas untuk mengeksplor diri dan fokus pada impiannya.

\section{7) Perjuangan dalam Meneruskan Kebaikan}

Kondisi Matari sekarang, yang telah berhasil menyelesaikan kuliah dan dapat bekerja di sebuah stasiun televisi adalah berkat dari kebaikan orang-orang sekitarnya juga. Karena Matari merasa mendapatkan sebuah kesempatan untuk mewujudkan impiannya dengan bantuan dari orang lain, maka ia ingin meneruskan kebaikan yang didapatkannya dengan memberi kebaikan pula pada orang lain.

Tari terenyak. Apa yang baru saja dikatakannya memang disampaikan dengan sepenuh hati. Sumbu emosinya jadi pendek setiap kali mendengar kata kuliah. la teringat utangnya. Tapi, di satu sisi ia juga ingin sekali bisa meneruskan kesempatan emas yang sudah didapatkannya untuk kuliah kepada orang lain. Uang, ia tidak punya, apalagi kalau bukan semangat yang bisa dibaginya. Pemberian terbaik yang ia punya saat ini...(Adenita, 2012:154).

Matari akan berusaha melakukan apapun yang bisa dilakukan untuk dapat meneruskan kebaikan dalam hidupnya. Jika sebuah materi belum ia miliki untuk membantu orang lain, maka sebuah semangat, senyuman, dan dukungan tetap bisa ia lakukan. Kutipan lain yang mendukung keinginan Matari untuk memperjuangkan dalam meneruskan kebaikan adalah sebagai berikut.

"23. 23 nama dalam buku ini luar biasa, Wan. 23 nama kebaikan yang pengen gue tulis dengan tinta emas. Angka yang bermakna besar dalam hidup gue. Gue harus meneruskan kebaikan 23 hati ini." Tari menatap uku dalam pengamatannya (Adenita, 2012:243)."

\section{c. Relevansi terhadap Materi Ajar Sastra di SMA}

Pembelajaran sastra di sekolah dengan menggunakan sebuah novel sudah diatur dan tercantum dalam silabus mata pelajaran Bahasa Indonesia Kurikulum 2013 tingkat SMA/MA/SMK/MAK yang dikeluarkan oleh Kementerian Pendidikan dan Kebudayaan (Kemdikbud). Pembelajaran yang menggunakan sebuah novel adalah pada semester genap kelas XII, yaitu dengan kompetensi dasarnya adalah: 3.7 menilai isi dua buku fiksi (kumpulan cerita pendek atau kumpulan puisi) dan satu buku pengayaan (nonfiksi) yang dibaca, 3.9 menganalisis isi kebahasaan novel. Maka dari itu, penelitian ini direlevansikan terhadap materi ajar sastra berdasarkan hasil penelitian perjuangan hidup tokoh utama pada novel 23 Episentrum karya Adenita.

\section{Pembahasan}

Novel 23 Episentrum karya Adenita adalah menceritakan perjalanan hidup seorang anak muda yang bernama Matari Anas. Seorang Sarjana Komunikasi Universitas Panaitan, Bandung, yang memiliki impian untuk menjadi seorang news anchor. Seorang anak muda yang ingin membuktikan bahwa pendidikan itu sangatlah penting dan dapat menunjang kehidupan yang jauh lebih baik. Menurut Djumransyah (dalam Dewi dkk., 2014:8), devinisi pendidikan dalam buku Filsafat 
Widya Prameswari Pertiwi, Imam Muhtarom, Dewi Herlina Sugiarti

Perjuangan Hidup Tokoh Utama Novel 23 Episentrum Karya Adenita dan Relevansinya terhadap Materi Ajar Sastra di SMA Tinjauan Sosiologi Sastra

Pendidikan adalah sebagai proses sosial yang dapat mempengaruhi individu. Pendidikan menuntut cara hidup seseorang, karena terjadinya modifikasi dalam pandangan hidup yang disebabkan pula oleh pengaruh antara interaksi, kecerdasan, perhatian, pengalaman, dan sebagainya.

Dengan demikian, pendidikan dapat mengantarkan tokoh utama dalam novel 23 Episentrum karya Adenita yang bernama Matari Anas ke dalam dunia pekerjaan yang diinginkannya. Saat itu, ia berusia 26 tahun. Matari masuk ke dunia kerja yang sebenarnya di Jakarta, ia diterima untuk bekerja di TvB (TV Berita) sebagai seorang reporter. Hal tersebut tentu bukanlah yang menjadi impiannya, tetapi memang itulah proses yang harus menjadi awal dalam kariernya sebelum sampai pada apa yang menjadi impiannya. Jauh sebelum itu, pada masa kuliahnya, ia pernah menjadi seorang reporter dan penyiar radio paruh waktu. Matari memang termasuk orang pekerja keras dan mau melakukan pekerjaan apapun yang bisa dilakukan.

Berdasarkan hasil penelitian, dapat ditemukan bahwa dibalik setiap ujian dalam hidup Matari, pengaruh lingkungan sangatlah mendukung perilaku dan karakternya. Maka dari itu, pentingnya sebuah lingkungan yang tepat akan memberi pengaruh yang baik pula pada kehidupan seseorang. Seperti lingkungan keluarga, pertemanan, dan pekerjaan. Dalam dunia pekerjaan, tentu Matari harus bersikap profesional, meski dengan sebuah beban utang yang masih saja belum terselesaikan. Karena bagaimana pun juga, dengan pekerjaan yang dimilikinya akan menjadi sebuah jalan untuk menyelesaikan utang-utangnya. Selain itu, tempat ia bekerja adalah sebuah kesempatan baginya untuk mencapai impiannya menjadi seorang news anchor. Meski dengan sebuah proses yang panjang dan tidak mudah bagi Matari untuk mencapainya.

Realitas sosial dalam novel 23 Episentrum karya Adenita dapat begitu dekat dengan pembaca, karena cerita di dalamnya mencerminkan kehidupan nyata. Bagaimana perjuangan seorang anak yang berasal dari keluarga berpenghasilan pas-pasan atau kondisi perekonomian yang sulit, harus berusaha lebih keras ketika ingin melanjutkan sekolah ke jenjang perkuliahan. Begitu pun dengan kondisi sosial dari novel 23 Episentrum karya Adenita, dapat begitu nyata dengan pekerjaan Matari sebagai seorang reporter di Jakarta. Banyaknya sebuah stasiun televisi di Jakarta yang saat ini sudah menjadi sebuah sarana masyarakat secara luas untuk menonton setiap acaranya. Bahkan, di dalam novel pun terdapat penjelasan ketika Matari harus membuat liputan di lokasi banjir. Keadaan yang sudah tidak asing lagi, ketika masuk musim hujan maka biasa terjadi di beberapa wilayah Indonesia yang terdampak banjir, terutama di Jakarta. Hal itu dapat disaksikan oleh masyarakat luas melalui berita-berita yang ditayangkan oleh televisi. Dan peran itulah yang ingin dilakukan oleh Matari, bekerja untuk menyampaikan berita kepada dunia.

Penelitian ini relevan dengan yang dilakukan oleh Sulis Budiarti (2013), Perjuangan Tokoh Utama Wanita dalam Novel Bidadari-Bidadari Surga Karya Tere Liye dan Skenario Pembelajarannya di Kelas XI SMA. Penelitian tersebut membahas mengenai wujud perjuangan dari tokoh utama wanita dalam sebuah novel dan implementasinya dalam pembelajaran gaya bahasa di kelas XI SMA. Perbedaan penelitian yang dilakukan oleh Sulis Budiarti dengan penelitian ini adalah terletak pada penggunaan novel dan teori yang digunakan dalam membedahnya. Penelitian ini menggunakan novel 23 Episentrum karya Adenita,

Silampari Bisa: Jurnal Penelitian Pendidikan Bahasa Indonesia, Daerah, dan Asing

Vol. 4, No. 2, 2021 
Widya Prameswari Pertiwi, Imam Muhtarom, Dewi Herlina Sugiarti

Perjuangan Hidup Tokoh Utama Novel 23 Episentrum Karya Adenita dan Relevansinya terhadap Materi Ajar Sastra di SMA Tinjauan Sosiologi Sastra

sedangkan Sulis Budiarti menggunakan novel Bidadari-Bidadari Surga karya Tere Liye. Kajian yang dilakukan dalam penelitiannya adalah menggunakan teori feminisme, sedangkan penelitian ini adalah menggunakan sosiologi sastra. Adapun persamaannya terletak pada fokus utama penelitiannya, yaitu sama-sama memfokuskan pada tokoh utama dalam novel untuk dikaji berdasarkan perjuangan hidupnya.

Selain itu, penelitian yang dilakukan oleh Andan Wahyu Karana (2013) dengan judul Kajian Sosiologi Sastra Tokoh Utama dalam Novel Lintang Karya Ardini Pangastuti B.N. membahas mengenai aspek sosiologi tokoh utamanya berdasarkan kajian struktur dan tinjauan sosiologi sastra. Perbedaan penelitian tersebut adalah menggunakan novel Lintang karya Ardini Pangastuti B.N., sedangkan penelitian ini adalah menggunakan novel 23 Episentrum karya Adenita. Selanjutnya, persamaannya adalah sama-sama menggunakan sosiologi sastra dalam mengaji konteks sosial pada novel berdasarkan tokoh utamanya. Tetapi, penelitian ini hanya berfokus pada sosiologi karya sastra saja.

Berikutnya adalah penelitian skripsi yang dilakukan oleh Margaretha Ervina Sipayung (2016) yang berjudul Konflik Sosial Tokoh Maryam dalam Novel Maryam Karya Okky Madasari:Kajian Sosiologi Sastra. Pembahasan dalam penelitiannya adalah menganalisis struktur dalam novel Maryam dengan hanya berfokus pada tokoh dan penokohan, alur, dan latar. Selain itu, fokus utamanya adalah untuk mengemukakan konflik sosial dalam novel Maryam. Bentuk dari konflik sosial dalam novel Maryam yang dikemukakan adalah konflik karena perbedaan orangperorangan, perbedaan antara individu dengan individu, perbedaan antara individu dengan kelompok, perbedaan antara kelompok dengan kelompok, dan konflik karena perbedaan kebudayaan.

Adapun perbedaan penelitian yang dilakukan oleh Margaretha Ervina Sipayung dengan penelitian ini adalah terletak pada kajian analisis yang dilakukan dan objek yang digunakan dalam penelitiannya. Penelitian Margaretha Ervina Sipayung adalah menganalisis berdasarkan konflik sosial tokoh Maryam dalam novel Maryam karya Okky Madasari, sedangkan penelitian ini menganalisis berdasarkan konteks sosial perjuangan hidup tokoh utama dalam novel 23 Episentrum karya Adenita. Persamaan dalam penelitian terletak pada tinjauan yang digunakan dalam melakukan penelitian, yaitu berdasarkan sosiologi sastra. Tetapi, penelitian ini hanya berfokus pada sosiologi karya sastra saja.

\section{Simpulan dan Saran}

Berdasarkan hasil penelitian dan pembahasan yang dilakukan terhadap novel 23 Episentrum karya Adenita, dapat disimpulkan hasil analisis perjuangan hidup tokoh utama dalam novel 23 Episentrum karya Adenita adalah menghasilkan: 1) perjuangan dalam bertahan hidup, 2) perjuangan untuk tetap bersyukur, 3) perjuangan dalam mewujudkan impian, 4) perjuangan untuk melunasi utang, 5) perjuangan dalam menjalankan pekerjaan, 6) perjuangan dalam mendapatkan kebahagiaan, dan 7) perjuangan dalam meneruskan kebaikan. Semua bentuk perjuangan yang dilakukan oleh Matari Anas sebagai tokoh utama adalah dipengaruhi oleh: 1) lingkungan keluarga, 2) lingkungan pertemanan, dan 3) lingkungan pekerjaan. Hasil penelitian tersebut dapat ditemukan berdasarkan tinjauan sosiologi karya sastra, yaitu mengaji aspek sosial yang terkandung di

Silampari Bisa: Jurnal Penelitian Pendidikan Bahasa Indonesia, Daerah, dan Asing Vol. 4, No. 2, 2021 
Widya Prameswari Pertiwi, Imam Muhtarom, Dewi Herlina Sugiarti

Perjuangan Hidup Tokoh Utama Novel 23 Episentrum Karya Adenita dan Relevansinya terhadap Materi Ajar Sastra di SMA Tinjauan Sosiologi Sastra

dalamnya untuk selanjutnya dikaitkan dengan kondisi sosial di luarnya. Penelitian ini dapat direlevansikan terhadap materi ajar sastra di SMA pada kelas XII semester genap.

Berdasarkan hasil penelitian ini, penulis memiliki beberapa saran sebagai berikut.

1. Peneliti, hasil penelitian ini dapat dijadikan sebagai acuan untuk perbandingan pada penelitian sejenis yang akan dilakukan.

2. Pembaca, hasil penelitian ini dapat menambah pengetahuan mengenai kajian dari sosiologi sastra terhadap sebuah novel, serta dapat menambah referensi bacaan untuk menumbuhkan minat baca terhadap karya sastra yang kaya akan nilai-nilai keteladanan.

3. Guru Bahasa dan Sastra Indonesia, hasil penelitian ini dapat memberikan referensi yang praktis terkait pemanfaatan novel 23 Episentrum karya Adenita terhadap materi ajar sastra.

4. Peserta didik, hasil penelitian ini diharapkan dapat menambah wawasan dan pengetahuan peserta didik mengenai keteladanan yang dapat dicontoh dari novel 23 Episentrum karya Adenita, sehingga meningkatkan pertumbuhan karakter dan kepribadian guna menghasilkan generasi penerus bangsa yang lebih baik.

\section{Daftar Pustaka}

Adenita. (2012). 23 Episentrum. Jakarta: PT Gramedia.

Budiarti, S. (2013). Perjuangan Tokoh Utama Wanita dalam Novel BidadariBidadari Surga Karya Tere Liye dan Skenario Pembelajarannya di Kelas XI SMA. Skripsi Program Studi pendidikan Bahasa dan Sastra Indonesia Universitas Muhammadiyah Purworejo: diterbitkan.

Dewi, N.L.L.A., dkk. (2014). Analisis Nilai-Nilai Pendidikan Karakter Novel Sepatu Dahlan Karya Khrisna Pabichara dan Relevansinya terhadap Pengajaran Pendidikan Karakter Sekolah di Indonesia. Jurnal Pendidikan Bahasa dan Sastra Indonesia Undiksha. 2 (1), https://ejournal.undiksha.ac.id/index.php/JJPBS/article/view/3438

Endraswara, S. (2011). Metodologi Penelitian Sosiologi Sastra. Yogyakarta: CAPS.

Karana, A. W. (2013). Kajian Sosiologi Sastra Tokoh Utama dalam Novel Lintang Karya Ardini Pangastuti B.N. Skripsi Program Studi Pendidikan Bahasa dan Sastra Jawa Universitas Muhammadiyah Purworejo: diterbitkan.

Kurniawan, H. (2012). Teori, Metode, dan Aplikasi Sosiologi Sastra. Yogyakarta: Graha IImu.

Maftuhin, dkk. (2016). Pendidikan Sosial Budaya. Bandung: CV. Maulana Media Grafika. 
Widya Prameswari Pertiwi, Imam Muhtarom, Dewi Herlina Sugiarti

Perjuangan Hidup Tokoh Utama Novel 23 Episentrum Karya Adenita dan Relevansinya terhadap Materi Ajar Sastra di SMA Tinjauan Sosiologi Sastra

Manesah, D. (2016). Representasi Perjuangan Hidup dalam Film Anak Sasada Sutradara Ponty Gea. Jurnal Proporsi. 1 (2), 179-189. http://ejournal.potensi-utama.ac.id/ojs/index.php/PROPORSI/article/view/523

Nilawijaya, R., \& Awalludin, A. (2021). Tinjauan Sosiologi Sastra dalam Novel Hafalan Shalat Delisa Karya Tere Liye dan Relevansinya terhadap Pembelajaran Sastra di SMA. Silampari Bisa: Jurnal Penelitian Pendidikan Bahasa Indonesia, Daerah, dan Asing, 4(1), 13-24. doi:10.31540/silamparibisa.v4i1.1212

Nugroho, A. \& Yasafiq. (2019). Perbandingan Nilai Sosial dalam Novel Ivanna Van Dijk dengan Novel Ananta Prahadi Karya Risa Saraswati Melalui Pendekatan Sosiologi Sastra. Silampari Bisa: Jurnal Penelitian Pendidikan Bahasa Indonesia, Daerah, dan Asing, 2(1), 29-43. https://doi.org/10.31540/silamparibisa.v2i1.271

Nurgiyantoro, B. (2013). Teori Pengkajian Fiksi. Yogyakarta: Gadjah Mada University Press.

Sipayung, Ma. E. (2016). Konflik Sosial dalam Novel Maryam Karya Okky Madasari: Kajian Sosiologi Sastra. Sintesis, 10(1), https://ejournal.usd.ac.id/index.php/sintesis/article/view/164.

Sugiyono. (2016). Metode Penelitian Kuantitatif, Kualitatif, dan R\&D. Bandung: Alfabeta, CV.

Sugiyono. (2020). Metode Peneltian Kualitatif. Bandung: CV Alfabeta.

Sujarwa. (2019). Model \& Paradigma TeoriSosiologi Sastra. Yogyakarta: Pustaka Pelajar.

Sulaeman, A., Goziyah, Purawinangun, I.A., Noermanzah. (2020). Social Value in the Novel Hatta: Aku Datang karena Sejarahby Sergius Sutanto as Teaching Materials in Teaching Literature in Schools. International Journal of Scientific and Technology Research, 9(3). 611-612. http://www.ijstr.org/paper-references.php?ref=IJSTR-0320-32332

Suryaman, M. (2010). Pendidikan Karakter Melalui Pembelajaran Sastra. Cakrawala Pendidikan, 3, 112-126. https://journal.uny.ac.id/index.php/cp/article/view/240 